Original Article

\title{
PHYLOGENETIC ANALYSIS OF FUSARIUM OXYSPORUMF STRAINS ISOLATED FROM STRAWBERRY CROPSFRAGARIA ANANASSADUCH IN THE PROVINCE OF PICHINCHA (ECUADOR)
}

\author{
ANGELICA TIGRE L. ${ }^{1}$, FREDY ERAZ01, DANILO YANEZ², FAVIAN BAYAS-MOREJON*
}

${ }^{1}$ Escuelas Superior Politecnica Del Chimborazo, Instituto de Posgrado y Educacion Continua, Riobamba, 060150, Ecuador, ${ }^{2}$ Universidad Estatal de Bolívar, Facultad de Ciencias Agropecuarias Recursos Naturales y del Ambiente, Departamento de Investigacion y Vinculacion, Centro de Investigación y Desarrollo Biotecnologico, Guaranda, 020150, Ecuador

Email: fbayas@ueb.edu.ec

Received: 20 Nov 2019, Revised and Accepted: 19 Jan 2020

\section{ABSTRACT}

Objective: Strawberry cultivation has acquired great importance for consumption, promoting the increase of its production in Ecuador. However, the process of importing plant material from producing countries in order to improve domestic production has contributed to the dissemination of the fungus Fusarium oxysporum $f$. sp. fragariae.

To identify the presence of the pathogen, by applying molecular techniques to the Fusarium strains isolated from strawberry crops.

Methods: Nine two diseased strawberry plants and 92 asymptomatic plants were analyzed. From these samples, 13 fungi with the characteristics of the Fusarium genus were identified. The isolates were analyzed at the molecular level, by PCR (Polymerase chain reaction) amplifying the ITS regions of the rDNA and the EF- $1 \alpha$ region.

Results: The PCR product was sequenced to elucidate the phylogenetic relationships between the isolates, identifying 12 strains as $F$. oxysporum $f$. sp. fragariae. These results confirmed the presence of the fungus in the strawberry crops analyzed, representing a contribution to the search for control alternatives to avoid the spread of the pathogen.

Conclusion: The PCR product was sequenced to elucidate the phylogenetic relationships between the isolates, identifying 12 strains as $F$. oxysporum $f$. sp. fragariae.

Keywords: Identification, Phylogenetic analysis, Fusarium, Strawberry

(C) 2020 The Authors. Published by Innovare Academic Sciences Pvt Ltd. This is an open access article under the CC BY license (http://creativecommons.org/licenses/by/4.0/) DOI: http://dx.doi.org/10.22159/ijcpr.2020v12i2.37516. Journal homepage: https://innovareacademics.in/journals/index.php/ijcpr

\section{INTRODUCTION}

Strawberry (Fragaria ananassa) has become a very important industrial crop worldwide, in fact, the demand for strawberries in the world is increasing. In Ecuador, $12 \%$ of strawberry producers are exported and the rest of producers satisfy domestic demand [1].

The specific pathogenicity of Fusarium oxysporum $f$. sp. fragariae has a negative impact on agriculture worldwide given that it is the cause of vascular wilt and basal rot of a large variety of plants, in Ecuador this fungus affects fruit crops such as babaco [2], strawberry, tomato kidney among others [3].

Nowadays, the use of new biotechnological technologies based on the Polymerase Chain Reaction (PCR) technique allows the rapid detection of pathogens present in plants and in the soil [4].

Restriction fragment length polymorphism, or RFLP. Random Amplification of Polymorphic DNA (RAPDs), among others, are used in the analysis of DNA genetic polymorphism, which with the development of bioinformatics software designed for sequence analysis, allows to obtain efficient and timely information applicable to multiple samples [5]. In this work it was proposed, identify, the fungus Fusarium oxysporum $f$. sp. fragariae, to establish its presence in strawberry crops in Ecuador, for which, by amplifying and sequencing the region of the intergenic spaces of the ribosomal DNA (ITS) and the Elongation Factor 1 alpha (EF-1 $\alpha)$.

\section{MATERIALS AND METHODS}

In this work 92 plants with symptoms such as: and 92 asymptomatic to the disease (soil/plant, root and leaves) were analyzed; these plants were in the phenological phases of vegetative development and fructification, according to the following procedure: Planting of the plant material (strawberry seedlings) was carried out on the previously prepared substrate of PDA (Potato dextrose agar, Oxoid, England), after a reseeding in selective medium MEA (Malt extract agar, Oxoid, England) the pathogen was isolated for conservation it

Molecular evaluation

It was evaluated at the molecular level (phylogenetic analysis) for which the amplification of the gene of interest was carried out by PCR using primers EF-1, EF-2, ITS-1, ITS-4 (table 1).

Table 1: Nucleotide sequences used for amplification of regions ITS (s) and TEF-1 $\alpha$

\begin{tabular}{lll}
\hline Primer & Sequence & Authors \\
\hline ITS-1 & 5'-TCCGTAGGTGAACCTGCGG-3' & Martin and rygiewicz [6] \\
ITS-4 & 5'-TCCTCCGCTTATTGATATGC-3' & 0'Donnell et al. [7] \\
EF-1 & 3'-ATGGGTAAGGARGACAAGAC-5' & \\
EF-2 & 3'-GGARGTACCAGTSATCATGTT-5' & \\
\hline
\end{tabular}

The amplification reaction was performed in a final volume of $25 \mu \mathrm{l}$, with $5 \mu \mathrm{L}$ of template DNA. Sterile ultrapure water was included as a negative control in each reaction. The components concentrations of the mixture were: $1.5 \mathrm{mmol} \mathrm{MgCl}_{2}, 0.2 \mathrm{mmol}$ de cada dNTP, $0.5 \mu \mathrm{M}$ of each primer, $1.25 \mathrm{U} / 25 \mu \mathrm{L}$ de Taq polymerase (FLEXI), PCR buffer (Green FLEX 1X). The amplification was carried out according to the 
following conditions: initial denaturation at $94{ }^{\circ} \mathrm{C}$ for $5 \mathrm{~min}, 35$ cycles at $94{ }^{\circ} \mathrm{C}$ for 30 seconds, primer binding at $53{ }^{\circ} \mathrm{C}$ for 60 seconds, initial extension at $72{ }^{\circ} \mathrm{C}$ for $1 \mathrm{~min}$ and a final extension at $72{ }^{\circ} \mathrm{C}$ for $10 \mathrm{~min}$. The PCR product was analyzed on a $0.5 \%$ agarose gel, in each electrophoretic analysis a molecular weight marker of 100 bp was used, the run of the gel was at 100 volts for $30 \mathrm{~min}$. The gel was visualized in a UV transilluminator (The Enduro ${ }^{\mathrm{TM}}$ GDS, USA).

The PCR products with nonspecific bands were purified. All the amplified ones were sent to sequence at MACROGEN in Seoul, South Korea (https://dna.macrogen.com), the results were compared with the GenBank database (NCBI, 2015). From the sequences of the EF-1 $\alpha$ and the RTS ITS regions, probabilistic models were applied; for multiple sequence alignment, the MUSCLE algorithm was used and the Maximun Likelihood Algorithm software was used for the phylogenetic trees. The sequences were contrasted with probable homologous genes available in the NCBI database (National Center for Biotechnology Information) using the BLAST local alignment application (Basic Local Alignment Search Tool) (www.ncbi.nlm.nih.gov/BLAST). The sequences obtained were edited and registered in the SeaView Version 4.5.4 program, for which the quality of the chromatograms was inspected, eliminating the bases that were not well defined.

\section{RESULTS AND DISCUSSION}

After isolation in PDA medium and confirmed its morphology by microscopic observation, all isolates were analyzed at the molecular level.

\section{Molecular evaluation}

The DNA concentration of the isolates obtained from the strawberry seedlings is shown in the table 2 .

Table 2: DNA concentration of the isolates obtained from strawberry plants Fragaria ananassa duch

\begin{tabular}{|c|c|c|}
\hline Treatments & Nucleic acids concentration $(\mathrm{ng} / \mu \mathrm{l})$ & $260 / 280$ \\
\hline $\mathrm{AB}_{1}$ & 4196.25 & 2.14 \\
\hline $\mathrm{AB}_{2}$ & 1542.90 & 2.19 \\
\hline $\mathrm{AB}_{3}$ & 1867.25 & 2.15 \\
\hline $\mathrm{AB}_{4}$ & 2475.70 & 2.08 \\
\hline $\mathrm{AB}_{5}$ & 555.85 & 2.11 \\
\hline $\mathrm{AB}_{6}$ & 4695.40 & 2.14 \\
\hline $\mathrm{AB}_{7}$ & 6546.45 & 2.05 \\
\hline $\mathrm{AB}_{8}$ & 696.05 & 2.08 \\
\hline $\mathrm{AB}_{9}$ & 84.40 & 1.87 \\
\hline $\mathrm{AB}_{10}$ & 1693.70 & 2.06 \\
\hline $\mathrm{AB}_{11}$ & 4598.75 & 2.09 \\
\hline $\mathrm{AB}_{12}$ & 119.95 & 1.97 \\
\hline $\mathrm{AB}_{13}$ & 2573.45 & 2.07 \\
\hline Pestalotia sp.* & 1536.55 & 2.00 \\
\hline Rhizoctonia sp. ${ }^{*}$ & 3255.40 & 2.19 \\
\hline
\end{tabular}

*Possible genres

The DNA of each isolate was quantified by spectrophotometry in a nano Drop One (Thermo Fisher scientific 8000 microvolume UV-Vis, USA), obtaining, as a result, a concentration range between 84.4 and $65.45 \mathrm{ng} / \mu \mathrm{l}$ and an average absorbance ratio of $2.0(260 / 280 \mathrm{This}$ average is framed in the relation between 1.7 and $2.0(260 / 280)$ [8] to define that DNA is pure.

\section{Phylogenetic analysis based on the ITS fragment}

It was carried out by PCR with the initiators ITS-1 and ITS-4, DNA of the 13 treatment and two possible pathogens previously characterized by optical microscopy such as Pestalotia sp. and Rhizoctonia sp. Where the 570 bp band was observed in the gel for the 13 treatments, including Pestalotia sp. In the case of Rizhoctonia sp. the band had a molecular weight slightly higher to $650 \mathrm{bp}$. The AB8 treatment and negative control (-) showed no visible band.
Multiple alignments with the MUSCLE algorithm based on the codons of the study sequences

The topology of the condensed tree obtained based on the ITS region started with the formation of a single group and a single divergent (polytomy), in the group 25 taxa are included, some of them grouped with good support and separated by small branches internal, also showing condensed branches that turned out to be polytomous. The rooting of the tree was achieved by including as sequences external groups of Fusarium oxysporum f. sp. fragariae (90436908), Fusarium oxysporum (827206934, 514825685 and 514825683). Sequences available in the NCBI nucleotide database (National Center for Biotechnology Information) found in the BLAST database. Relationships received moderate-high bootstrap support (0.83-0.92) in the maximum verisimilitude analysis (fig. 1).

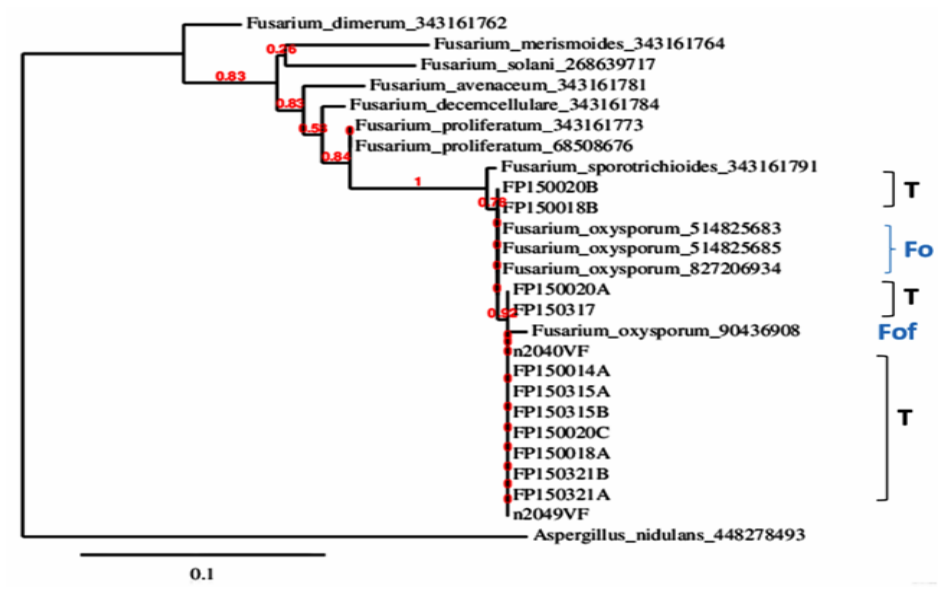

Fig. 1: Consensus tree constructed with the maximum verisimilitude method, based on the distances of the sequences of the regions of the internal transcribed spacer (ITS) in the ribosomal DNA; (T) treatments, (Fo) Fusarium oxysporum, (Fof) Fusarium oxysporum f. sp. Fragariae 
Also, can be observed that the 9 reference sequences were grouped into a single clade (branch) with Fusarium oxysporumf. sp. fragariae (90436908). The rooting shows that Fusarium oxysporum $f$. sp. Fragariae and the strains are monophyletic based on the sequences to the ITS regions.

\section{Phylogenetic analysis based on the EF-1 $\alpha$ region}

The amplification and sequencing of the EF- $1 \alpha$ region were carried out with the EF1-EF2 primers plus the DNA of the 13 treatments. After PCR amplification, bands of $570 \mathrm{bp}$ were visualized for the 13 treatments and the presence of nonspecific bands was observed in each of the isolates, so the Band-stab PCR technique was carried out in all the isolates.

The amplification of the products extracted with the Band-stab PCR technique allowed the visualization a band of $680 \mathrm{bp}$ in the 13 treatments $\left(\mathrm{AB}_{1}-\mathrm{AB}_{13}\right)$, with the follow concentrations of DNA: 80 $\mathrm{ng} / \mu \mathrm{l}\left(\mathrm{AB}_{2}, \mathrm{AB}_{3}, \mathrm{AB}_{4}, \mathrm{AB}_{5}, \mathrm{y} \mathrm{AB}_{8}\right), 100 \mathrm{ng} / \mu \mathrm{l}\left(\mathrm{AB}_{1}, \mathrm{AB}_{6}, \mathrm{AB}_{7}, \mathrm{AB}_{9}\right.$, $\left.\mathrm{AB}_{10}, \mathrm{AB}_{11}, \mathrm{AB}_{12} \mathrm{y} \mathrm{AB}_{13}\right)$.

After sequencing in MACROGEN, the results were edited and registered in the Sea View program. The quality of the chromatograms was examined by eliminating bases not well defined and the result obtained was of $631 \mathrm{bp}$ of acceptable quality. Multiple alignments were performed, applying the MUSCLE algorithm, under the default configuration in the Sea View program they showed similarity in the nucleotides, except for small differences in the treatments $\mathrm{AB}_{2}, \mathrm{AB}_{3}$, and $\mathrm{AB}_{12}$, but a very significant difference in the alignment of the nucleotides of the $\mathrm{AB}_{4}$ treatment (fig. 2). The alignment between the treatments establishes that the $\mathrm{AB}_{4}$ treatment presents different nucleotide zones with the other treatments, determining that there is no degree of similarity between the amino acids.

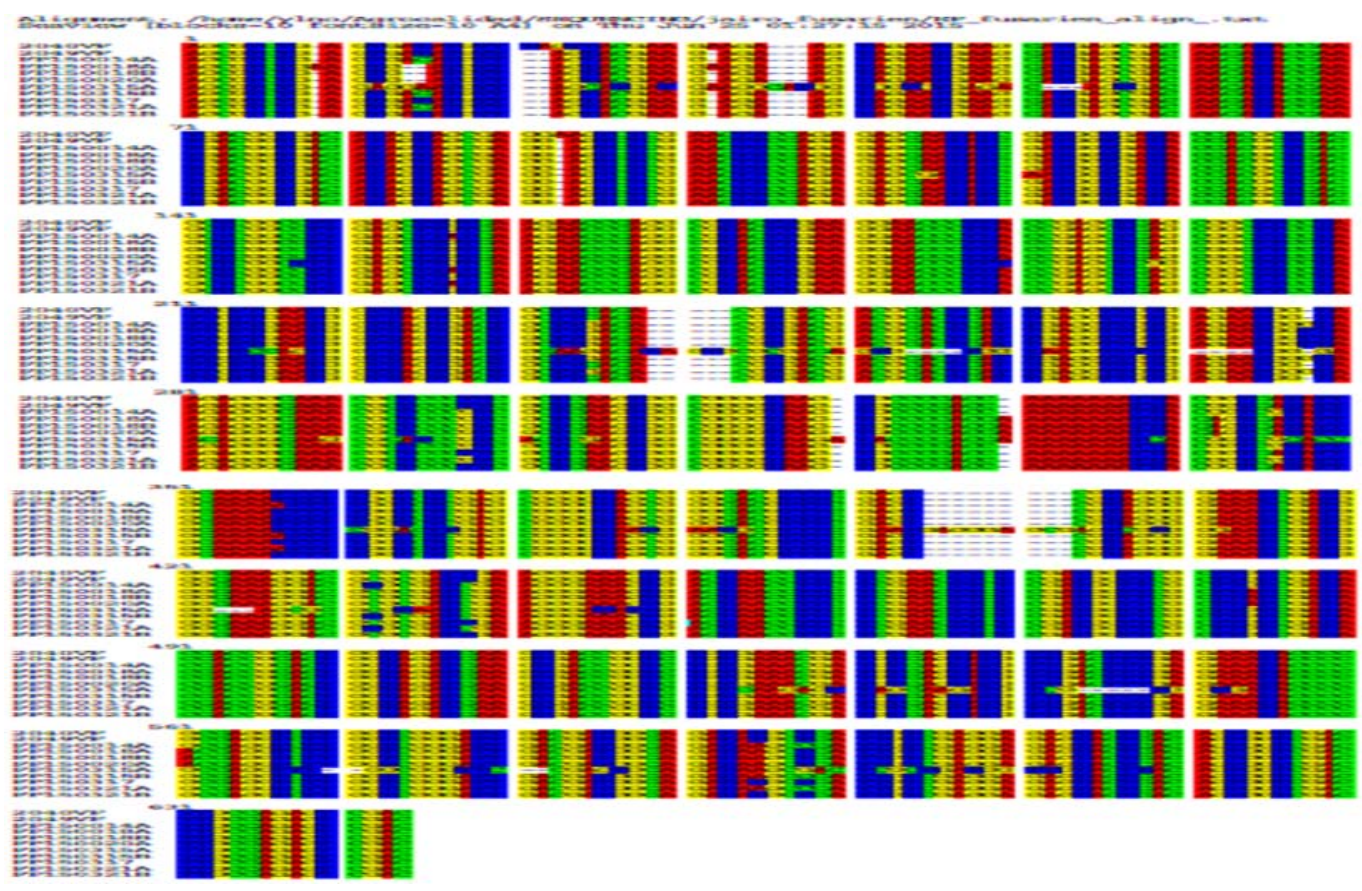

Fig. 2: Multiple alignments with the MUSCLE algorithm based on codons of the study sequences

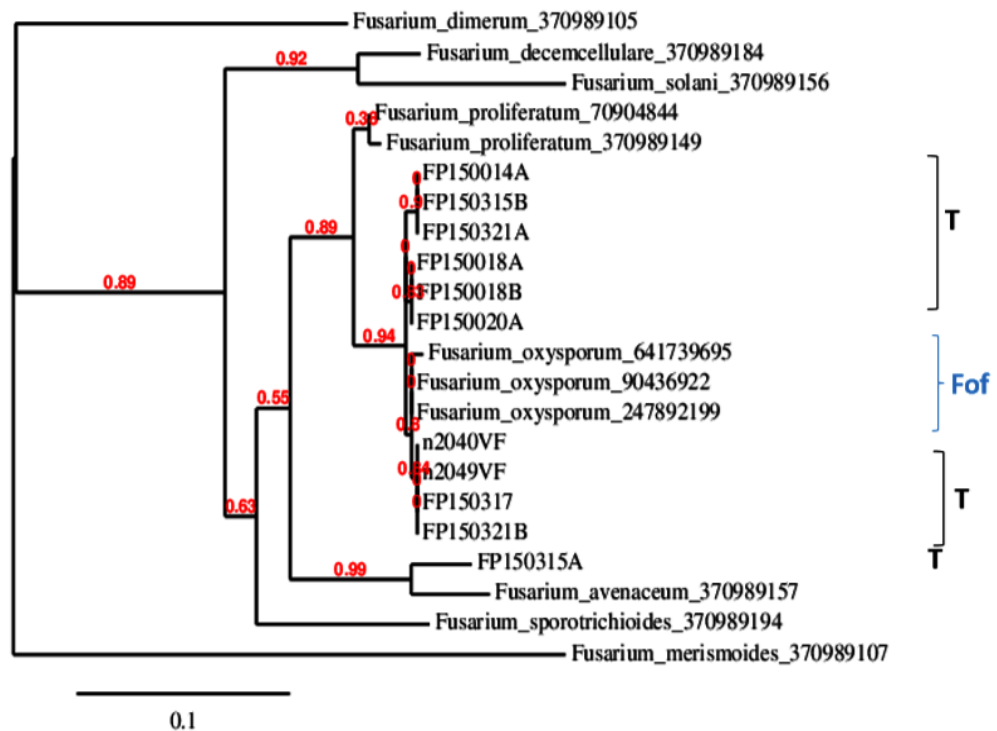

Fig. 3: Consensus tree constructed with the maximum verisimilitude method, based on the distances of the sequences of the EF $1 \alpha$ region of the DNA: (T) treatments, (Fof) Fusarium oxysporum f. sp. Fragariae 
The cladogram was constructed based on the sequences of the EF- $1 \alpha$ regions, with the maximum verisimilitude method visualizing 2 initial clades, in the formation of a single initial group and a single divergent (polytomy), in the group 25 taxes are included, some of them grouped with good support and separated by small internal branches, also protruding condensed branches that turned out to be polytomous. In the formation of the clades, sequences of other genera and sequences of Fusarium oxysporumf were used. sp. fragariae (90436922, 641739695, 2478921999), sequences available in the NCBI database (2015) (fig. 3).

In this cladogram, the sequences of treatments $\mathrm{AB}_{5}$ and $\mathrm{AB}_{6}$ were excluded because their sequences decay rapidly with few base pairs. Relationships received moderate-high bootstrap support (0.89-0.94) in the maximum verisimilitude analysis

Other authors have previously studied the ITS and EF- $1 \alpha$ regions, demonstrating their effectiveness in resolving some generated ambiguities and taxonomically locating new species of the Fusarium genus [9]. Although the use of universal primers allows us to study the inter-specific variability and establish identifications when comparing the obtained sequences with others previously deposited in the GenBank database, it should be noted that the best tool to identify quickly, unequivocally and less expensively the different species of fungi associated with vascular wilt is the use of specific primers [10], but everything will depend on the purity of the isolates and the PCR products, so several procedures were carried out until the best result.

\section{Evaluation of the special form of Fusarium oxysporum with specific initiators}

The specific oligonucleotides designed for Fusariumoxysporum $f \mathrm{sp}$. Fragariae Fofra-1 and Fofra-2 [11], used in the PCR reaction, showed no amplification in the 13 DNA samples. Therefore, it should be taken into account that the isolates used in this investigation did not amplify because there are differences in evolution between species from one locality to another [12].

On the other hand, no significant statistical differences were detected between the treatments for the distribution, determining that there are no differences between the variables. The coefficient of variation is $19.46 \%$, acceptable for field evaluation.

\section{ACKNOWLEDGMENT}

The authors express their full gratitude to the State of Bolivar University, and to the debt exchange program Ecuador-Spain, for the support received in carrying out the present work.

\section{FUNDING}

\section{AUTHORS CONTRIBUTIONS}

All the authors have contributed equally.

\section{CONFLICT OF INTERESTS}

Declare none

\section{REFERENCES}

1. MAGAP-DPP. Ministry of agriculture livestock aquaculture and fisheries-provincial directorate of pichincha, unit of technological innovation, priority crops, executive report; 2015. p. 16. Available from:http://sinagap.agricultura.gob.ec/phocadownloadpap/temat icos_zonales/precios_produccion/2016/precios_productor_mayo_ 2016_zona2.pdf. [Last accessed on 05 Oct 2019]

2. Robles A, Gomez R, Macas F, Sanchez A, Torrez Gutierrez. Estudio de la patogenicidad de aislados de Fusarium spp., asociados a la marchitez vascular del babaco en loja-ecuador. Revista Electronica Centro de Biotecnologia 2014;3:63-74.

3. Jaramillo J. Agronomic evaluation of the kidney tomato crop (Solanum lycopersicum) under three different plastic coverings. Thesis. San Francisco University of Quito; 2015. Available from: repository.usfq.edu.ec.pdf [Last accessed 13 Aug 2017]

4. Henry PM, Kirkpatrick SC, Islas CM, Pastrana AM, Yoshisato JA, Koike ST, et al. The population of Fusarium oxysporum f. sp. fragariae, cause of Fusarium wilt of strawberry, in california. Plant Disease 2017;101:550-6.

5. Dawidziuk A, Koczyk G, Popiel D, Kaczmarek J, Busko M. Molecular diagnostics on the toxicogenic potential of Fusarium spp. plant pathogens. J Appl Microbiol 2014;116:1607-20.

6. Martin J, Rygiewicz PT. Fungal-specific PCR primers developed for analysis of the ITS region of environmental DNA extracts. BMC Microbiol 2005;5:11.

7. O'Donnell K, Kistler HC, Cigelnik E, Ploetz RC. Multiple evolutionary origins of the fungus causing panama disease of banana: concordant evidence from nuclear and mitochondrial gene genealogies. Proc Natl Acad Sci USA 1998;95:2044-9.

8. Maniatis T, Fritsch EF, Sambrook J. Molecular cloning: a laboratory manual, X+545. S., 61 Abb., 28 Tab. Cold Spring Harbor NY. 2 ${ }^{\text {nd }}$ Ed. Cold Spring Harbor Laboratory; 1982. p. 16.

9. Fang X, You MP, Barbetti MJ. Reduced severity and impact of Fusarium wilt on strawberry by soil $\mathrm{pH}$ manipulation, soil organic amendments and crop rotation. Eur J Plant Pathol 2012;134:619.

10. Koike ST, Kirkpatrick SC, Gordon TR. Fusarium wilt of strawberry caused by Fusarium oxysporum in california. Plant Disease 2009;93:1077.

11. Suga H, Hirayama Y, Morishima M, Suzuki T, Kageyama K, Hyakumachi M. Development of PCR primers to identify Fusarium oxysporum f. sp., fragariae. Plant Disease 2013;97:619-25.

12. Sambrook J, Russell DW. Molecular cloning: a laboratory manual. Cold Spring Harbor Laboratory Press; 2001. p. 2344. 